\title{
Delayed Tree Mortality and Chinese Tallow (Triadica sebifera) Population \\ Explosion in a Louisiana Bottomland Hardwood Forest Following Hurricane
}

\author{
Katrina \\ Theryn K. Henkel ${ }^{\mathrm{a}, 1}$, Jeffrey Q. Chambers ${ }^{\mathrm{a}, 2}$ and David A. Baker ${ }^{\mathrm{a}}$ \\ ${ }^{a}$ Department of Ecology and Evolutionary Biology, Tulane University, 400 Boggs, New Orleans, Louisiana \\ 70118, USA \\ ${ }^{1}$ Coastal Sustainability Program, Lake Pontchartrain Basin Foundation, 2045 Lakeshore Drive Suite 339, \\ New Orleans, Louisiana, 70122, USA \\ ${ }^{2}$ Department of Geography, University of California at Berkeley, 505 McCone Hall \#4740 Berkeley, \\ California, 94720, USA \\ *Corresponding Author: therynhenkel@gmail.com
}

\section{Abstract}

Assessing long-term effects of hurricane damage in bottomland hardwood forests is important to detect any permanent, long lasting changes to the forest. Two $75 \times 75$ meter plots were established in a Louisiana bottomland hardwood forest in 2004 and all adult trees were measured. The plots were resurveyed in 2006 after Hurricane Katrina passed over the plots in 2005, and in 2011, to gain an understanding of mortality over time. Species composition, mortality and biomass change were assessed over the study period from 2004 to 2011. Sweetgum, water oak, and laurel oak were the most important overstory species in 2004, and American holly and American hornbeam were the most important understory species. In the more damaged plot, there was a shift in dominant species as 63 new Chinese tallow individuals recruited into the adult class $(>10 \mathrm{~cm})$ between 2004 and 2011 . Chinese tallow is an invasive tree species that often out-competes native species in bottomland hardwood forests. Annual mortality in the bottomland hardwood forest plots between 2004 and 2011 was $6 \%$ per 
year, 11\% per year from 2004 to 2006 (representing direct hurricane mortality), and 5\% between 2006 and 2011 (delayed tree mortality). Approximately $53 \%$ of the total biomass $(188,000 \mathrm{~kg})$ was lost between 2004 and 2011. A plot in a cypress tupelo forest was added in 2006 and very little damage or mortality was observed. This study revealed that delayed mortality to hurricane-damaged trees is a significant factor in the long-term dynamics of bottomland hardwood forests and represents an amplification of the effects of the hurricane over time. The fact that direct and delayed mortality is different by species indicates that the measurement only of direct mortality can lead to false conclusions about which species are resistant to hurricanes. Hurricane damage opened up new habitat for invasion by Chinese tallow which grew prolifically in highly damaged, low elevation, wet areas, indicating that large disturbances are an important factor in accelerating the population expansion of this invasive species. The high mortality and low recruitment of some species into the sapling and adult layers and the corresponding expansion of Chinese tallow indicates that species composition will differ from prehurricane composition for some time in the future.

\section{Keywords}

Hurricane Katrina, Bottomland Hardwood Forest, Triadica sebifera, Invasive Species, Delayed Mortality, Disturbance

\section{1}

\section{Introduction}

Assessing long-term effects of hurricane damage in bottomland hardwood forests is important to ascertain if there are any permanent, long lasting changes to the forest ecosystem caused by the hurricane passage, and if so what these changes are. Recovery of a mixed hardwood forest over a seven year period in Florida following tropical-storm-force winds from Hurricane Kate in 1985 showed that indirect, delayed mortality of hurricane-damaged trees was greater that direct hurricane mortality 
(Batista and Platt 2003). However, hurricane induced mortality was not differentiated from background or natural mortality, so all of the delayed mortality cannot be attributed just to the hurricane.

Succession was accelerated after Hurricane Hugo in a South Carolina bottomland hardwood forest when established shade-intolerant pioneer species were killed by the hurricane, releasing the advance recruits of shade-tolerant climax species (Zhao et al. 2006) and liana densities increased over time (Allen et al. 2005).

Species composition can change over time after a forest experiences extensive hurricane damage as not all species are damaged and/or experience mortality at the same rate (Gresham et al. 1991; Chapman et al. 2008). Seed sources of some species may be diminished and conditions created by hurricane damage (high light due to canopy loss, increase in nutrients) may favor some species establishment over others. Investigations into changes in species composition due to hurricane damage have revealed mixed results. While Zhao et al. (2006) found little change in species composition in the above study, Battaglia et al. (1999) found high loblolly pine (Pinus taeda) mortality and low recruitment in another study. Alterations to the species composition due to hurricane damage can be variable among forests because changes are determined, in part, by the species composition before the hurricane, individual species susceptibility to windthrow or snapping, and hurricane intensity.

Documentation of invasive species dynamics pre- and post-hurricane is rare. One study found that Chinese tallow (tallow hereafter) (Triadica sebifera) increased in importance nine years after Hurricane Hugo in Cape Romain National Wildlife Refuge (Conner et al. 2005). In that study, before the storm, tallow had a stem density of 63 stems/ha; nine years later, tallow had a stem density of 1269.4 stems/ha even though tallow also experienced significant damage during the storm. In another case, an herbaceous native species, bamboo (Arundinaria gigantea), expanded through clonal growth after wind disturbance and formed dense monotypic stands that prevented the establishment of native forest tree seedlings (Gagnon et al. 2007; Gagnon and Platt 2008). Introduction or range expansion of exotic species 
can affect forest recovery by preventing native species regeneration or increasing competition which slows recovery. Also, large changes in species composition can affect the forest ecology and the ecosystem services the forest provides to wildlife (food, shelter, mating habitat).

There have been few studies conducted investigating the long-term effects of hurricane passage on mortality or damage, forest recovery, subsequent mortality of damaged trees and invasive species spread. This study investigated the effects of Hurricane Katrina (2005) on a bottomland hardwood forest in Louisiana's Pearl River Wildlife Management Area (PRWMA), from 2004 (pre- hurricane) to 2011 in order to obtain delayed mortality estimates of damaged trees. Ascertaining delayed mortality also allows for calculation of additional biomass (and therefore carbon) loss from this forest which has implications in regional carbon cycling as well as future climate change, especially if the intensity and frequency of hurricanes in the region increase, as predicted (Emanuel 2005; Webster et al. 2005; Saunders and Lea 2008; Wu and Wang 2008). The present study also investigated the effect of hurricane passage on invasive species (tallow) range expansion and assessed forest recovery by surveying the new generation of trees recruiting into the adult and sapling stages. Combining assessments of delayed mortality, invasive species spread, and the next generation of the forest will allow for estimation of forest health, future forest species composition, and recommendations for management of bottomland hardwood forest in southeast Louisiana.

\section{2}

\section{Methods}

\subsection{1}

\section{Study site}

Field surveys were conducted in the PRWMA located at the border of Louisiana and Mississippi

(Figure 1). The PRWMA contains 14,176 hectares and is owned and managed by the Louisiana Department of Wildlife and Fisheries. It is the largest area of intact bottomland hardwood forest (BLH) in 
the southeastern United States (http://www.wlf.louisiana.gov). The management area is comprised of mixed bottomland hardwood forests dominated by oaks (Quercus spp.), sweetgum (Liquidambar styraciflua), hickories (Carya spp.), and elms (Ulmus spp.) in the northern $60 \%$, changing to cypress-tupelo forest in the next $25 \%$, and finally intermediate marsh at the extreme southern end. The northern part of the PRWMA experiences intermittent flooding except in bayous and swales where flooding is more frequent. Further south, the BLH experiences seasonal flooding. The cypress-tupelo forests experience seasonal flooding as well but the soils are permanently saturated except during extreme drought. Water levels are generally highest in late winter to early spring with flooding lasting one to three months in the seasonally flooded forests (White 1983). This research was carried out at the northern end of the management area (north of Interstate 10) at approximately N30.397083 and W89.702611 in the Honey Island Swamp.

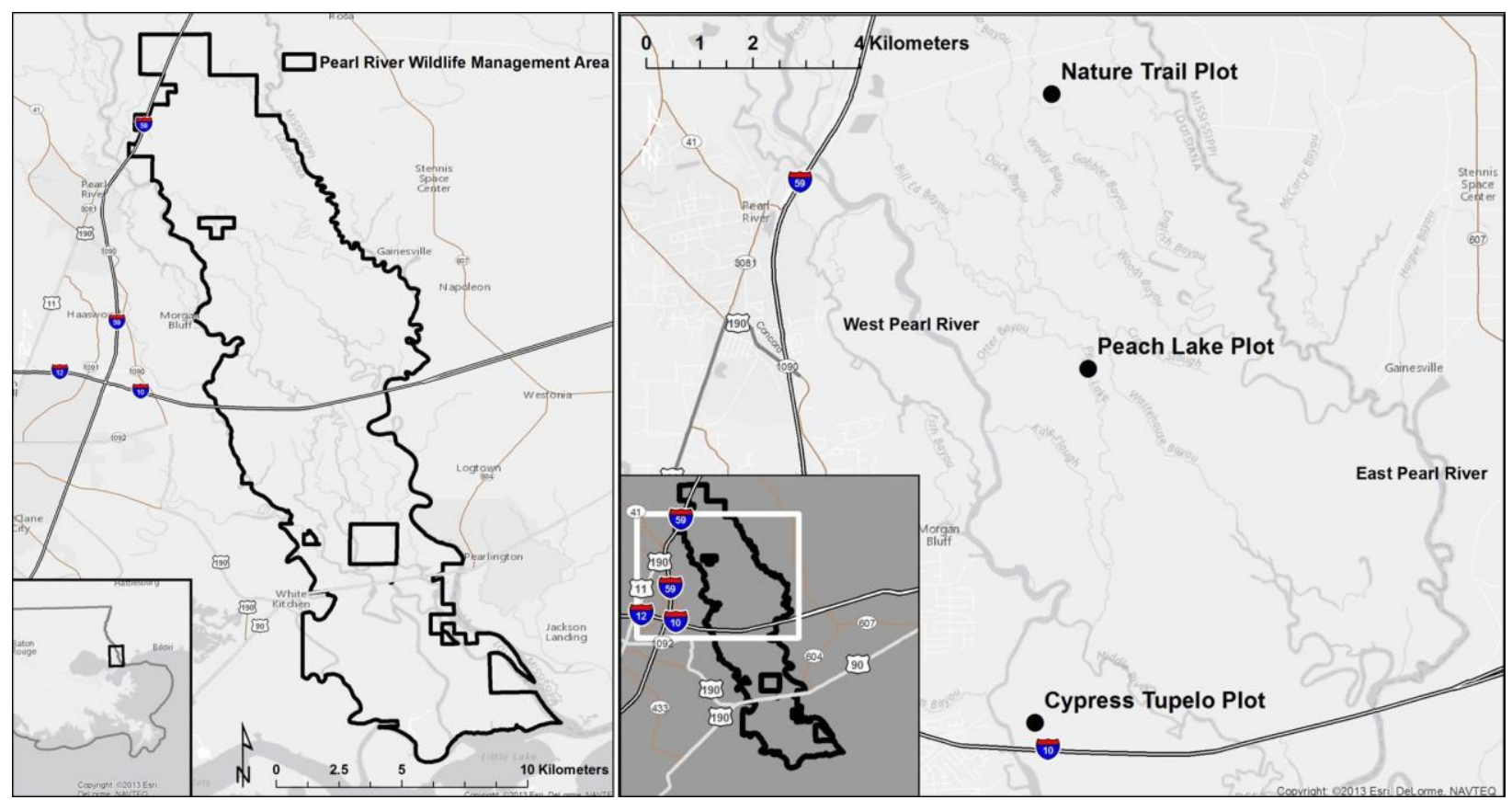

Figure 1: Location of the Pearl River Wildlife Management Area along the Louisiana/Mississippi border and the location of the Nature Trail, Peach Lake and Cypress Tupelo plots within the Management area.

\subsection{2}




\section{Design}

Hurricane Katrina made landfall on August 29, 2005 at the mouth of the Pearl River on the Louisiana and Mississippi border with sustained winds of $195 \mathrm{~km} \mathrm{~h}^{-1}$ and gusts up to $240 \mathrm{~km} \mathrm{~h}^{-1}$. The central track of the hurricane moved up the Pearl River passing over the PRWMA. The plots used in this study are located 19 to 29 kilometers inland from Lake Borgne.

Spectral mixture analysis (Chambers et al. 2007) was used on Landsat images to quantify abundance of green vegetation, non-photosynthetic vegetation (NPV), soil and shade. Downed woody vegetation represented by the NPV values were compared using May 29, 2003 and June 6, 2006 images, and the change in NPV ( $\triangle N P V)$ between the two images was a useful measure of the damage caused by Hurricane Katrina. The Landsat images had a resolution of $30 \times 30$ meter pixels with the NPV value obtained for each pixel representing the percentage of that area that was non-photosynthetic vegetation. Thus, the $\triangle N P V$ value represents the difference in percent non-photosynthetic vegetation per pixel between the 2003 and 2006 images on a pixel by pixel comparison. The $\triangle N P V$ value was used to establish plots over a range of damage levels ( $\triangle N P V$ from 0 to 0.3 ; i.e. there was $30 \%$ more nonphotosynthetic vegetation in 2006 than in 2003) in PRWMA. Adult tree damage and mortality levels over a range of forest damage were investigated in the field to ground truth the results of the remote sensing analysis. Using the field data, the Chambers group confirmed a correlation between $\triangle N P V$ values and adult tree mortality and damage $\left(r^{2}=0.85\right.$ for when comparing $\triangle N P V$ and actual mortality and $r^{2}=0.88$ when comparing $\triangle N P V$ to mortality plus snapped trees).

In 2004, two $75 \times 75$ meter plots were established by the Chapman et al. (2008) group in the PRWMA (Figure 1). These plots were divided into nine $25 \times 25$ meter sub-plots to ease surveying. One plot was located just south of old Highway 11 (Nature Trail plot). The second plot was located about one kilometer further south near the end of Oil Well Road (Peach Lake plot). In each of these plots, all adult trees (greater than $10 \mathrm{~cm} \mathrm{DBH}$ ) were tagged in 2004, species noted, and DBH measured. These plots 
were resurveyed in the summer of 2006 after Hurricane Katrina during which tagged trees were located and $\mathrm{DBH}$, mortality, type of damage, and snap height were measured, if applicable (Chapman et al. 2008). Additionally, the crown of all the trees were surveyed and given a score from one to four, one being little crown damage (0-25\% missing or damaged) and four being the crown was severely damaged or missing (75-100\%). Also in 2006, a third $75 \times 75$ meter plot (Cypress Tupelo plot) was established approximately 330 meters north of I-10 (Figure 1). This plot is located in cypress-tupelo swamp and adult trees were tagged, DBH measured, and stems were assessed for damage and death due to the hurricane as above. The three plots sustained different amounts of damage. The Nature Trail ( $\triangle \mathrm{NPV}=$ 0.15 ; range $=0.08-0.25)$ and Cypress Tupelo $(\Delta N P V=0.03 ;$ range $=0.0007-0.06)$ plots experienced less damage from Hurricane Katrina than the Peach Lake plot $(\Delta N P V=0.22 ;$ range=0.12-0.3).

The three plots were resurveyed in the summer of 2011. Tagged trees were located and DBH was measured to ascertain growth rates. It was also noted if trees were dead that were not dead in the 2006 survey. New trees that recruited into the adult stage class ( $>10 \mathrm{~cm} \mathrm{DBH}$ ) were recorded and measured. Saplings ( $2 \mathrm{~cm}$ to $10 \mathrm{~cm} \mathrm{DBH}$ ) were also surveyed by counting the number of individuals and recording the species of each.

\subsection{3}

\section{Analysis}

Species composition was analyzed by calculating importance values (IV) for each adult species in each plot, in each year, using relative abundance, frequency and dominance (Eq. 1) (Curtis and McIntosh 1951). Importance values were used because they are applicable when working in environmental gradients and are useful for comparing across plots to ascertain dominant species and can detect gross differences in vegetation composition (Greig-Smith 1983; Kent 2012). 
Equation 1: Equations used to calculated importance values. Relative dominance was only used for adult trees since sapling DBH was not collected.

Equation 1: Equation for Calculating Importance Values (IV)

$$
\begin{gathered}
\text { IV }=\text { relative frequency }+ \text { relative density }+ \text { relative dominance } \\
\text { Frequency }=\frac{\# \text { of plots in which species occurs }}{\text { total } \# \text { of plots }}
\end{gathered}
$$$$
\text { Relative Frequency }=\left(\frac{\text { frequency of individual species }}{\sum \text { frequencies for all species }}\right) * 100
$$$$
\text { Density }=\frac{\text { Total } \# \text { of individuals of a species }}{\text { total area measured }}
$$$$
\text { Relative Density }=\left(\frac{\text { density of individual species }}{\sum \text { densities for all species }}\right) * 100
$$$$
\text { Dominance }=\frac{\sum \text { basal area of a species in all plots }}{\text { total area measured }}
$$

Relative Dominance $=\left(\frac{\text { total basal area of a species }}{\sum \text { dominance for all species }}\right) * 100$

Percent mortality for the time period of 2004 to 2006 for the Nature Trail and Peach Lake plots were taken from Chapman et al. (2008) and delayed mortality for the period 2006 to 2011 was calculated as well as overall mortality from 2004-2011. Additionally, calculations of percent annual mortality were performed using the recommended formula in Sheil et al. (1995). Biomass change was calculated by species, along with overall biomass change from 2004 to 2011 (Table 1).

Table 1: Allometric equations used to calculate tree biomass and changes in biomass over time.

\begin{tabular}{|ccc|}
\hline Species Name & Allometric biomass equation* & Source \\
\hline Acer rubrum & $\mathrm{Y}=\left(2.39959^{*}\left(\mathrm{D}^{2}\right)^{1.2003}\right)^{*} 0.4536$ & Martin et al. 1998 \\
Carpinus caroliniana & $\mathrm{Y}=\left(2.47910^{*}\left(\mathrm{D}^{2}\right)^{1.23265}\right)^{*} 0.4536$ & Clark et al. 1986b \\
Carpinus caroliniana & $\mathrm{Y}=\left(3.0018^{*}\left(\mathrm{D}^{2}\right)^{1.19280 * 0.4536}\right.$ & Clark et al. 1986b \\
Carya aquatica & $\log _{10} \mathrm{Y}=\left(-1.326+2.762\left(\log _{10} \mathrm{D}\right)\right)^{*} 0.4536$ & Ter-Mikaelian and Korzukhin 1997 \\
Diospyros virginiana & $\mathrm{Y}=\left(1.69699^{*}\left(\mathrm{D}^{2}\right)^{1.27523}\right)^{*} 0.4536$ & Jenkins et al. 2003 \\
Fagus grandifolia & $\left.\left(\log _{10} \mathrm{Y}=\left(2.342+2.155 \log _{10} \mathrm{D}\right)\right)\right) / 1000$ & Fatemi et al. 2011 \\
Fraxinus pennsylvanica & $\ln \mathrm{Y}=\left(-5.31+0.92436 \ln \left(\mathrm{D}^{2}\right)^{*} \mathrm{H}\right) * 0.4536$ & Schlaegel 1984 \\
Fraxinus pennsylvanica & $\mathrm{H}=4.5+\mathrm{e}^{5.2309+\left(-3.7257^{*} \mathrm{D}^{\wedge}-0.5013\right)}$ & Schlaegel 1984 \\
llex decidua & $\mathrm{Y}=\left(1.69699^{*}\left(\mathrm{D}^{2}\right)^{1.27523}\right)^{*} 0.4536$ & Jenkins et al. 2003 \\
llex opaca & $\mathrm{Y}=\left(1.69699 *\left(\mathrm{D}^{2}\right)^{1.27523}\right) * 0.4536$ & Jenkins et al. 2003
\end{tabular}




\begin{tabular}{|c|c|c|}
\hline Ilex verticillata & $Y=\left(1.69699 *\left(D^{2}\right)^{1.27523}\right) * 0.4536$ & Jenkins et al. 2003 \\
\hline Liquidambar styraciflua & $Y=\left(1.57902 *\left(D^{2}\right)^{1.28241}\right) * 0.4536$ & Clark et al. $1986 \mathrm{~b}$ \\
\hline Liquidambar styraciflua & $Y=\left(1.23675^{*}\left(D^{2}\right)^{1.33335}\right) * 0.4536$ & Clark et al. $1986 b$ \\
\hline Magnolia grandiflora & $Y=\left(1.4359 *\left(D^{2.5622}\right)\right) * 0.4536$ & Brenneman et al. 1978 \\
\hline Magnolia virginiana & $Y=\left(1.4359 *\left(D^{2.5622}\right)\right) * 0.4536$ & Brenneman et al. 1978 \\
\hline Nyssa aquatica & $Y=\left(2.43427^{*}\left(D^{2}\right)^{1.16974}\right) * 0.4536$ & Ter-Mikaelian and Korzukhin 1997 \\
\hline Nyssa sy/vatica & $Y=\left(2.43427 *\left(D^{2}\right)^{1.16974}\right)^{*} 0.4537$ & Ter-Mikaelian and Korzukhin 1997 \\
\hline Ostrya virginiana & $Y=\left(1.69699 *\left(D^{2}\right)^{1.27523}\right) * 0.4536$ & Jenkins et al. 2003 \\
\hline Planera aquatica & $Y=\left(2.17565 *\left(D^{2}\right)^{1.24810}\right) * 0.4536$ & Clark et al. 1986a \\
\hline Quercus laurifolia & $Y=\left(2.89221 *\left(D^{2}\right)^{1.21296}\right) * 0.4536$ & Colbert et al. 2002 \\
\hline Quercus lyrata & $Y=\left(2.97559 *\left(D^{2}\right)^{1.21433}\right) * 0.4536$ & Jenkins et al. 2003 \\
\hline Quercus michauxii & $Y=\left(2.97559 *\left(D^{2}\right)^{1.21433}\right) * 0.4537$ & Jenkins et al. 2003 \\
\hline Quercus nigra & $Y=\left(3.15067 *\left(D^{2}\right)^{1.21955}\right) * 0.4536$ & Jenkins et al. 2003 \\
\hline Taxodium distichum & $Y=\left(3.15067 *\left(D^{2}\right)^{1.21955}\right) * 0.4536$ & Jenkins et al. 2003 \\
\hline Triadica sebifera & $Y=\left(2.4316 *\left(D^{2}\right)^{1.20782}\right) * 0.4536$ & Clark et al. 1986b \\
\hline Ulmus americana & $Y=\left(2.17565 *\left(D^{2}\right)^{1.24810}\right) * 0.4536$ & Clark et al. $1986 a$ \\
\hline
\end{tabular}

$\mathrm{Y}=$ biomass $(\mathrm{kg}) ; \mathrm{D}=$ diameter at breast height; $\mathrm{H}=$ total height of tree,

* Where two biomass equations are listed, the first applies to $\mathrm{DBH}<28 \mathrm{~cm}$ and the second for $\mathrm{DBH}>28 \mathrm{~cm}$

\section{3}

\section{Results}

\subsection{1}

\section{Species Composition}

\subsubsection{1}

\section{Nature Trail Plot}

In the Nature Trail plot, 205 individuals of 14 species were measured in 2004. Red maple (27 individuals), American hornbeam (35), sweetgum (45), blackgum (32) and water oak (30) were the most abundant species (scientific names are found in Table 2), with sweetgum and water oak having the highest IV (Table 2). The most important understory species were American hornbeam and American 
holly. Since importance value takes into account frequency, abundance, and size, the most abundant species may not be the most important, as seen with water oak which had fewer individuals than American hornbeam and blackgum but had a higher importance value. In 2006, after Hurricane Katrina, the same five species were still the most important. However, the IV for water oak decreased between 2004 and 2006 and moved from being the most important species in the plot to second most important after sweetgum. Blackgum, red maple, and American hornbeam demonstrated a slight increase in IV. By 2011, water oak was again the most important species in the plot but sweetgum demonstrated a decrease in IV between 2006 and 2011.

In the Nature Trail plot, 55 new adults of 12 species recruited into the plot between 2004 and 2011. The understory species American hornbeam (20 individuals) and American holly (13), had the most new adults. American elm had 4 new individuals and the rest of the canopy species had 3 or less. The sapling layer demonstrated different patterns than the adult layer. There were 868 sapling individuals found in 2011, representing 25 species. In the sapling layer the most abundant species were American holly (281 individuals), water oak (267), American hornbeam (61) and possumhaw (49).

\subsubsection{2}

Peach Lake Plot

In the Peach Lake plot, there were 240 individuals of 17 species in 2004. Laurel oak (54 individuals), sweetgum (46) and American hornbeam (24) were the most abundant in 2004. The five most important species were laurel oak, sweetgum, green ash, overcup oak and American hornbeam. The most important understory species were American hornbeam and possumhaw. In 2006 there was a shift in species importance with sweetgum becoming most important, then laurel oak, bald cypress, blackgum, green ash and water tupelo. A major shift was seen in 2011 when the most important species, which was not part of the adult canopy in 2004, was the invasive species, tallow. The next two most important species were still laurel oak and sweetgum but the importance values for these species 
decreased. Bald cypress, blackgum, green ash and American hornbeam maintained similar importance values to those calculated for 2006. Tallow most likely achieved a high importance value by being very abundant (63 individuals) and being found ubiquitously throughout the plot. All of the tallow trees that recruited into the adult size class $(>10 \mathrm{~cm} \mathrm{DBH}$ ) by 2006 were small (average $\mathrm{DBH}=11.9)$ so contributed little to total basal area.

In the Peach Lake plot, 111 new adults, of 10 species, recruited into the plot between 2004 and 2011. The majority (63) of the new trees were the invasive tallow. Thirteen of the new individuals were American hornbeam while blackgum and laurel oak had eleven new individuals each. The remaining species had 4 new individuals or less. The sapling layer demonstrated a different pattern than the canopy layer in 2011. There were 423 individual saplings found, representing 20 species. The most important sapling in the plot was tallow, dominating because of high abundance (313 individuals or $77 \%$ of all sapling individuals found in the plot). The next most important species was the understory dominant American hornbeam which was also the next most abundant species (15 individuals).

\subsubsection{3}

\section{Cypress Tupelo Plot}

In the Cypress Tupelo plot, 602 individuals were measured in 2006, representing four species. The most abundant species was water tupelo with 565 individuals, while bald cypress had 23 individuals, blackgum had 13 individuals and red maple had one individual. Water tupelo was also the most important species in the plot (Table 2). Bald cypress was the next most important followed by blackgum and red maple. This trend continued in 2011 with IV's being very similar to those from 2006. In the Cypress Tupelo plot, six new adults recruited into the plot between 2006 and 2011, five water tupelo and one bald cypress. The sapling layer was more diverse than the canopy layer having 75 individuals, representing seven species. 
Table 2: Importance values for adults in the Nature Trail, Peach Lake and Cypress Tupelo plots over time and for saplings in 2011.

\begin{tabular}{|c|c|c|c|c|c|c|c|c|c|c|c|c|}
\hline \multirow{2}{*}{$\begin{array}{l}\text { Species } \\
\text { Scientific Name }\end{array}$} & \multirow[b]{2}{*}{ Common Name } & \multicolumn{4}{|c|}{ Nature Trail Plot } & \multicolumn{4}{|c|}{ Peach Lake Plot } & \multicolumn{3}{|c|}{ Cypress Tupelo Plot } \\
\hline & & 2004 & 2006 & 2011 & Saplings & 2004 & 2006 & 2011 & Saplings & 2006 & 2011 & Saplings \\
\hline Acer rubrum & red maple & 34.0 & 38.3 & 29.9 & 9.2 & 16.3 & 11.3 & 9.5 & 8.7 & 4.5 & 4.5 & 37.4 \\
\hline Carpinus caroliniana * & American hornbeam & 34.7 & 35.7 & 38.5 & 14.5 & 21.8 & 18.3 & 21.9 & 14.1 & & & 5.9 \\
\hline Carya aquatica & water hickory & 2.2 & 2.4 & 4.8 & & 10.1 & 11.5 & 7.9 & 3.1 & & & \\
\hline Cephalanthus occidentalis* & buttonbush & & & & & & & & 6.9 & & & 7.2 \\
\hline Cornus florida* & flowering dogwood & & & & 1.9 & & & & & & & \\
\hline Crataegus marshallii* & parsley hawthorn & & & & 2.8 & & & & & & & \\
\hline Crataegus viridis* & green hawthorn & & & & 9.7 & & & & 6.4 & & & \\
\hline Cyrilla racemiflora* & swamp titi & & & & 0.9 & & & & & & & \\
\hline Diospyros virginiana & persimmon & 4.1 & 4.4 & 2.0 & & 3.8 & 4.3 & 0.0 & 3.1 & & & \\
\hline Fagus grandifolia & American beech & 0.0 & 0.0 & 2.1 & 2.2 & & & & & & & \\
\hline Fraxinus pennsylvanica & green ash & & & & & 25.2 & 26.8 & 23.6 & 8.5 & & & 5.9 \\
\hline Halesia diptera* & two-wing silverbell & & & & 6.2 & & & & 1.6 & & & \\
\hline Hamamelis virginiana* & American witchhazel & & & & 3.2 & & & & & & & \\
\hline Ilex decidua * & possumhaw & & & & 13.1 & 4.8 & 4.1 & 9.1 & 10.7 & & & \\
\hline Ilex opaca* & American holly & 20.4 & 20.0 & 25.3 & 39.9 & 1.6 & 2.1 & 1.7 & & & & \\
\hline Ilex verticillata* & common winterberry & & & & & 3.7 & 4.8 & 2.1 & 7.9 & & & \\
\hline Ilex vomitoria* & yaupon & & & & 0.9 & & & & & & & \\
\hline Liquidamber styraciflua & sweetgum & 63.4 & 71.8 & 49.7 & 3.1 & 51.5 & 56.8 & 36.2 & 3.1 & & & \\
\hline Magnolia grandiflora & southern magnolia & 2.1 & 2.3 & 5.6 & 2.8 & & & & & & & \\
\hline Magnolia virginiana & sweetbay & 12.8 & 14.1 & 13.0 & 8.7 & & & & & & & \\
\hline Nyssa aquatica & water tupelo & & & & & 16.0 & 23.3 & 22.2 & 3.3 & 219.6 & 218.7 & 114.2 \\
\hline Nyssa sylvatica & blackgum & 37.1 & 42.9 & 38.6 & 10.8 & 19.5 & 26.9 & 25.1 & 6.7 & 27.8 & 27.9 & 11.8 \\
\hline Ostrya virginiana * & hophornbeam & 2.1 & 2.2 & 2.0 & & & & & & & & \\
\hline Pinus glabra & spruce pine & & & & 0.9 & & & & & & & \\
\hline Planera aquatica & water elm & & & & & 5.5 & 4.3 & 5.9 & 1.6 & & & \\
\hline Quercus laurifolia & laurel oak & 2.0 & 2.2 & 5.9 & 7.4 & 63.9 & 52.0 & 39.5 & 9.8 & & & \\
\hline Quercus lyrata & overcup oak & & & & & 24.9 & 17.2 & 14.1 & 3.1 & & & \\
\hline Quercus michauxii & swamp chestnut oak & 11.4 & 13.4 & 12.8 & 4.7 & & & & & & & \\
\hline Quercus nigra & water oak & 68.9 & 44.9 & 59.5 & 38.3 & 8.6 & 6.1 & 4.7 & & & & \\
\hline Quercus shumardii & Shumard's oak & & & & & & & & 1.6 & & & \\
\hline Sambucus nigra ssp. Canadensis* & American black elderberry & & & & 8.3 & & & & & & & \\
\hline Salix nigra & black willow & & & & & & & & 2.0 & & & \\
\hline Taxodium distichum & bald cypress & & & & 0.9 & 18.2 & 28.2 & 28.4 & & 48.0 & 48.9 & 17.6 \\
\hline Triadica sebifera & Chinese tallow & & & & 0.9 & 0.0 & 0.0 & 42.3 & 85.8 & & & \\
\hline Ulmus alata & winged elm & & & & 1.9 & & & & & & & \\
\hline Ulmus americana & American elm & 4.8 & 5.3 & 10.4 & 6.3 & 4.6 & 2.2 & 5.6 & 12.0 & & & \\
\hline
\end{tabular}




\subsection{2}

\section{Mortality}

\subsubsection{1}

\section{Nature Trail Plot}

Between 2004 and 2006, the Nature Trail plot experienced 11\% mortality with 23 of 205 trees dying after Hurricane Katrina. Five species experienced mortality during this time. Water oak experienced the greatest mortality with 13 out of 30 trees dying (43\% mortality; Table 3). American holly had three out of 14 trees die ( $21 \%$ mortality). American holly is an understory species and most likely experienced collateral damage from other trees and large pieces of trees (branches, crowns) falling. All other species had mortality levels below $10 \%$ after the hurricane. However, out of the remaining 182 trees, 91 were damaged (50\%). Damage consisted of partial crown loss, entire crown loss (snapped), partial or entire uproot, leaning and pinned. Ten of the species had damaged individuals. Using mortality calculation methods from Sheil et al. (1995), the Nature Trail plot experienced an annual mortality of $6 \%$ per year from 2004 to 2006 . Water oak experienced the highest annual mortality of $22 \%$ per year. American holly, an understory species, experienced an annual mortality of $11 \%$ per year from 2004 to 2006, while other species had an annual mortality of less than $4 \%$.

Between 2006 and 2011 there was mortality of trees that experienced damage during Hurricane Katrina (Table 3). During this time, 25\% of the trees present in 2006 died. Therefore, total mortality from 2004 to 2011 in the Nature Trail plot was 33\%. However, some trees experienced no visible damage during the hurricane but subsequently died between 2006 and 2011. During high winds, trees can twist and bend, which can cause internal damage that is not visible, thus death of trees without visible damage can be attributed to the hurricane. However, in order to be conservative, subsequent mortality and total mortality that can be confidently attributed to the hurricane at $18 \%$ between 2006 and 2011 and 29\% from 2004 to 2011. 
Between 2006 and 2011, 10 of the 14 species experienced mortality. The highest mortality was experienced by sweetgum with 18 trees dying, for a total mortality between 2004 and 2011 of $47 \%$. Eleven of these sweetgum individuals were snapped off by the hurricane. American Hornbeam experienced the next highest mortality with ten individuals dying resulting in a total mortality from 2004 to 2011 of $37 \%$. Annual mortality rates from 2006 to 2011 were $13 \%$ per year for persimmon and $11 \%$ per year for sweetgum indicating high rates of delayed mortality to damaged trees. Annual mortality rates for American holly, American hornbeam and red maple were 6\%, 7\%, and 5\%, respectively.

During this study, mortality in the Nature Trail plot was approximately 3.0 times higher than would be expected from background mortality rates (1.9\% as calculated by Chapman et al. [2008] for all species). Water oak, sweetgum and persimmon experienced an annual mortality rate of $9 \%$ per year throughout the study period, while American holly, American hornbeam, red maple, and swamp chestnut oak experienced annual mortality rates of $8 \%, 6 \%, 4 \%$, and $3 \%$, respectively. All other species had annual mortality rates similar or below expected background mortality rates for this forest.

\subsubsection{2}

\section{Peach Lake Plot}

Between 2004 and 2006, the Peach Lake plot experienced 31\% mortality or 74 individuals out of 240 died (Table 3). Thirteen out of the 17 species experienced mortality during this time. The species that experienced the highest mortality was water oak with four out of six individuals dead (67\%) but the species with most individuals dying was laurel oak with 23 out of 54 individuals dying (43\%). American hornbeam experienced the next greatest mortality with twelve out of 24 individuals dead (50\%). Overcup oak had seven out of 17 individuals die (41\%). Overall, oak species experienced $44 \%$ mortality with 34 out of 77 individuals dead. Sweetgum also experienced high mortality at $28 \%$ (13 out of 46 individuals dead). Green ash experienced 33\% mortality (six out of 18 individuals dead) and red maple experienced 38\% mortality (three out of eight individuals dead). Overall annual mortality between 2004 
and 2006 in this plot was 15\% per year. Water oak experienced an annual mortality of 33\%, American elm and American hornbeam 25\%, laurel and water oak 21\%, red maple 19\%, persimmon, green ash and possumhaw $17 \%$ and sweetgum at $14 \%$.

Out of the remaining 166 trees in 2006, 106 of them (64\%) and 16 out of the 17 species were damaged in the hurricane. For four species, $100 \%$ of the remaining individuals had damage including persimmon ( 2 individuals), American holly (1), common winterberry (3) and water oak (2). American hornbeam and sweetgum had the next highest damage rates at 83\% (10 individuals) and 82\% (27), respectively. Of the remaining ten species, eight of them had damage rates of $50 \%$ or higher, including blackgum (76\%; 13 individuals), laurel oak (74\%; 23$)$, green ash $(58 \% ; 10)$, water elm $(66 \% ; 2)$, water hickory $(50 \% ; 3)$, possumhaw $(50 \% ; 1)$, water tupelo $(50 \% ; 6)$, and overcup oak $(50 \% ; 10)$.

Between 2006 and 2011 the Peach Lake plot experienced 26\% mortality (Table 3). Therefore, total mortality between 2004 and 2011 was $49 \%$ or 117 individuals died ( $9 \%$ annual mortality). However, if trees that showed no visible damage from the hurricane in 2006 are removed then total mortality between 2004 and 2011 is $47 \%$ (only five trees died that were not damaged in 2006). Ten out of the 17 species present experienced delayed mortality. Sweetgum was the species with the most individuals damaged in the hurricane and the most individuals dying between 2006 and 2011; 15 individuals died during this time or $33 \%$ of the trees that were present in 2004 (45\% of the trees remaining in 2006), giving sweetgum a total mortality between 2004 and 2011 of $61 \%$ or an annual mortality of $13 \%$. Laurel oak had nine individuals die between 2006 and 2011 (17\% of trees present in 2004, 29\% of trees remaining in 2006) and had a total mortality between 2004 and 2011 of 59\% or an annual mortality of 12\%. Species with the highest total mortality (between 2004 and 2011) were persimmon which had $100 \%$ mortality (all three individuals present) and water oak which had $83 \%$ mortality or $23 \%$ annual mortality. Blackgum experienced a total mortality (2004 to 2011) of $39 \%$ or $7 \%$ annual mortality. 
Based upon the background mortality rate of $1.9 \%$ that has been determined for this forest (Chapman et al. 2008), and the annual mortality rate of $9 \%$ over the same time period, mortality in this plot was approximately 4.7 times higher than would be expected from background mortality rates.

\subsubsection{3}

\section{Cypress Tupelo Plot}

Since this plot was established in 2006 there are no data from 2004 to 2006 . When the plot was established in 2006, there were no dead trees present, but there was evidence of damage. Of the 602 trees present, 60 showed signs of hurricane damage, mostly in the form of snaps. An additional 64 trees (11\%) were noted as looking "stressed". Combining these observations, $20 \%$ of the trees in this plot had damage or were showing signs of stress after the hurricane.

Between 2006 and 2011, 38 individuals of the 602 trees died or 6\% (Table 3). Water tupelo experienced the highest mortality at $7 \%$ with 37 individuals dead out of 565 trees. One out of 23 bald cypress individuals died during this time (4\%). Background mortality rates could not be found for cypress-tupelo forest types. Annual mortality in this plot from 2006 to 2011 was calculated at 1\%. No species in the plot had annual mortality rates higher than $1 \%$. 
Table 3: Mortality rates in Nature Trail and Peach Lake plots from 2004 to 2006 and 2006 to 2011 and for the Cypress Tupelo plot from 2006 to 2011 . Mortality is calculated for the time intervals as well as total mortality from 2004 to 2011. Also the number of new adults and the number of saplings found in 2011 is shown.

\begin{tabular}{|c|c|c|c|c|c|c|c|c|c|c|c|c|c|c|c|c|c|c|c|c|c|}
\hline \multirow[b]{2}{*}{ Scientific Name } & \multicolumn{8}{|c|}{ Nature Trail Plot } & \multicolumn{8}{|c|}{ Peach Lake Plot } & \multicolumn{5}{|c|}{ Cypress Tupelo Plot } \\
\hline & $\begin{array}{l}\text { Total } \\
2004\end{array}$ & $\begin{array}{l}\text { Dead } \\
2006\end{array}$ & $\%$ & $\begin{array}{l}\text { Dead } \\
2011\end{array}$ & $\%$ & $\begin{array}{c}\text { Total } \\
\text { Mortality }\end{array}$ & $\begin{array}{c}\text { New } \\
\text { Adults }\end{array}$ & $\begin{array}{c}\text { New } \\
\text { Saplings }\end{array}$ & $\begin{array}{l}\text { Total } \\
2004\end{array}$ & $\begin{array}{l}\text { Dead } \\
2006\end{array}$ & $\%$ & $\begin{array}{l}\text { Dead } \\
2011\end{array}$ & $\%$ & $\begin{array}{c}\text { Total } \\
\text { Mortality }\end{array}$ & $\begin{array}{c}\text { New } \\
\text { Adults }\end{array}$ & $\begin{array}{c}\text { New } \\
\text { Saplings }\end{array}$ & $\begin{array}{l}\text { Total } \\
2006\end{array}$ & $\begin{array}{l}\text { Dead } \\
2011\end{array}$ & $\%$ & $\begin{array}{c}\text { New } \\
\text { Adults }\end{array}$ & $\begin{array}{c}\text { New } \\
\text { Saplings }\end{array}$ \\
\hline Acer rubrum & 27 & 1 & $4 \%$ & 6 & $22 \%$ & $26 \%$ & 2 & 22 & 8 & 3 & $38 \%$ & 2 & $25 \%$ & $63 \%$ & 3 & 9 & 1 & 0 & $0 \%$ & & 11 \\
\hline Carpinus caroliniana * & 35 & 3 & $9 \%$ & 10 & $29 \%$ & $37 \%$ & 20 & 61 & 24 & 12 & $50 \%$ & 3 & $13 \%$ & $63 \%$ & 13 & 15 & & & & & 1 \\
\hline Carya aquatica & 1 & 0 & $0 \%$ & 0 & $0 \%$ & $0 \%$ & 2 & & 7 & 1 & $14 \%$ & 1 & $14 \%$ & $29 \%$ & & 2 & & & & & \\
\hline Cephalanthus occidentalis* & & & & & & & & & & & & & & & & 7 & & & & & 2 \\
\hline Cornus florida* & & & & & & & & 2 & & & & & & & & & & & & & \\
\hline Crataegus marshallii* & & & & & & & & 3 & & & & & & & & & & & & & \\
\hline Crataegus viridis* & & & & & & & & 26 & & & & & & & & 5 & & & & & \\
\hline Cyrilla racemiflora* & & & & & & & & 1 & & & & & & & & & & & & & \\
\hline Diospyros virginiana & 2 & 0 & $0 \%$ & 1 & $50 \%$ & $50 \%$ & & & 3 & 1 & $33 \%$ & 2 & $67 \%$ & $100 \%$ & & 2 & & & & & \\
\hline Fagus grandifolia & & & & & & & 1 & 5 & & & & & & & & & & & & & \\
\hline Fraxinus pennsylvanica & & & & & & & & & 18 & 6 & $33 \%$ & 2 & $11 \%$ & $44 \%$ & & 8 & & & & & 1 \\
\hline Halesia diptera* & & & & & & & & 18 & & & & & & & & 1 & & & & & \\
\hline Hamamelis virginiana* & & & & & & & & 6 & & & & & & & & & & & & & \\
\hline Ilex decidua * & & & & & & & & 49 & 3 & 1 & $33 \%$ & 0 & $0 \%$ & $33 \%$ & 4 & 12 & & & & & \\
\hline Ilex opaca* & 14 & 3 & $21 \%$ & 3 & $21 \%$ & $43 \%$ & 13 & 281 & 1 & 0 & $0 \%$ & 0 & $0 \%$ & $0 \%$ & & & & & & & \\
\hline llex verticillata * & & & & & & & & & 3 & 0 & $0 \%$ & 0 & $0 \%$ & $0 \%$ & & 11 & & & & & \\
\hline Ilex vomitoria* & & & & & & & & 1 & & & & & & & & & & & & & \\
\hline Liquidamber styraciflua & 45 & 3 & $7 \%$ & 18 & $40 \%$ & $47 \%$ & 3 & 5 & 46 & 13 & $28 \%$ & 15 & $33 \%$ & $61 \%$ & 2 & 2 & & & & & \\
\hline Magnolia grandiflora & 1 & 0 & $0 \%$ & 0 & $0 \%$ & $0 \%$ & 3 & 3 & & & & & & & & & & & & & \\
\hline Magnolia virginiana & 7 & 0 & $0 \%$ & 1 & $14 \%$ & $14 \%$ & 1 & 25 & & & & & & & & & & & & & \\
\hline Nyssa aquatica & & & & & & & & & 12 & 0 & $0 \%$ & 0 & $0 \%$ & $0 \%$ & & 3 & 565 & 37 & $7 \%$ & 5 & 55 \\
\hline Nyssa sylvatica & 32 & 0 & $0 \%$ & 4 & $13 \%$ & $13 \%$ & 3 & 29 & 18 & 1 & $6 \%$ & 6 & $33 \%$ & $39 \%$ & 11 & 6 & 13 & 0 & $0 \%$ & & 2 \\
\hline Ostrya virginiana & 1 & 0 & $0 \%$ & 0 & $0 \%$ & $0 \%$ & & & & & & & & & & & & & & & \\
\hline Pinus glabra & & & & & & & & 1 & & & & & & & & & & & & & \\
\hline Planera aquatica & & & & & & & & & 4 & 1 & $25 \%$ & 0 & $0 \%$ & $25 \%$ & & 1 & & & & & \\
\hline Quercus Iaurifolia & 1 & 0 & $0 \%$ & 0 & $0 \%$ & $0 \%$ & 2 & 14 & 54 & 23 & $43 \%$ & 9 & $17 \%$ & $59 \%$ & 11 & 8 & & & & & \\
\hline Quercus lyrata & & & & & & & & & 17 & 7 & $41 \%$ & 2 & $12 \%$ & $53 \%$ & 1 & 2 & & & & & \\
\hline Quercus michauxii & 6 & 0 & $0 \%$ & 1 & $17 \%$ & $17 \%$ & & 5 & & & & & & & & & & & & & \\
\hline Quercus nigra & 30 & 13 & $43 \%$ & 1 & $3 \%$ & $47 \%$ & 1 & 267 & 6 & 4 & $67 \%$ & 1 & $17 \%$ & $83 \%$ & 1 & & & & & & \\
\hline Quercus shumardii & & & & & & & & & & & & & & & & 1 & & & & & \\
\hline Sambucus nigra ssp. Canadensis* & & & & & & & & 29 & & & & & & & & & & & & & \\
\hline Salix nigra & & & & & & & & & & & & & & & & 3 & & & & & \\
\hline Taxodium distichum & & & & & & & & 1 & 14 & 0 & $0 \%$ & 0 & $0 \%$ & $0 \%$ & & & 23 & 1 & $4 \%$ & 1 & 3 \\
\hline Triadica sebifera & & & & & & & & 1 & & & & & & & 63 & 313 & & & & & \\
\hline Ulmus alata & & & & & & & & 2 & & & & & & & & & & & & & \\
\hline Ulmus americana & 3 & 0 & $0 \%$ & 0 & $0 \%$ & $0 \%$ & 4 & 11 & 2 & 1 & $50 \%$ & 0 & $0 \%$ & $50 \%$ & 2 & 12 & & & & & \\
\hline *understory species & 205 & 23 & $11 \%$ & 45 & $22 \%$ & $33 \%$ & 55 & 868 & 240 & 74 & $31 \%$ & 43 & $18 \%$ & $49 \%$ & 111 & 423 & 602 & 38 & $6 \%$ & 6 & 75 \\
\hline
\end{tabular}




\subsection{3}

\section{Biomass Change}

\subsubsection{1}

\section{Nature Trail Plot}

The Nature Trail plot experienced a 50\% net loss in biomass between 2004 to 2011 (Table 4). Between 2004 and 2006, there was a 44\% loss in biomass and between 2006 and 2011 there was 11\% biomass loss (6\% of the biomass that was present in 2004). This represents a loss of $77,097 \mathrm{~kg}$ of biomass from 2004 to 2011 (-67,429 kg from 2004-2006; -9,667 kg from 2006-2011). The species with the highest percent biomass losses were American hornbeam at 59\%, sweetgum at $56 \%$, water oak at $55 \%$ and red maple at $53 \%$. For all four of these species, percent biomass loss was higher than percent mortality. The species with the most biomass loss were sweetgum $(20,645 \mathrm{~kg})$ and water oak $(45,035$ $\mathrm{kg}$ ). The species with the most percent biomass gain between 2004 and 2011 were southern magnolia (360\%), laurel oak (231\%), American elm (191\%) and hophornbeam (100\%). Of these species the most biomass gain was American elm (501 kg). While hophornbeam gained 100\% of its biomass this only represents a $45 \mathrm{~kg}$ biomass gain while water hickory gained $51 \%$ biomass which corresponded to $127 \mathrm{~kg}$. Overall, nine of the 14 species had a net loss in biomass in this plot and five species had a net gain between 2004 and 2011.

\subsubsection{2}

\section{Peach Lake Plot}

The Peach Lake plot experienced 56\% biomass loss between 2004 and 2011 (Table 4). Between 2004 and 2006 there was $44 \%$ biomass loss and between 2006 and 2011 there was $21 \%$ loss (12\% of the biomass present in 2004). This represents a loss of 110,986 kg from 2004 to 2011 in this plot (-87,025 kg 2004 to 2006 and $-23,961 \mathrm{~kg}$ from 2006 to 2011). The species with the highest percent biomass loss in the plot were persimmon (100\%; all three trees in the plot died), laurel oak (81\%), overcup oak (81\%), 
red maple (79\%) and water oak (75\%). The species with the most biomass loss were laurel oak $(59,991$ $\mathrm{kg})$, sweetgum $(22,462 \mathrm{~kg})$ and overcup oak $(17,240 \mathrm{~kg})$. Overall, the three oak species in the plot (laurel, overcup and water oak) represent $41 \%$ of the $56 \%$ lost between 2004 and 2011 (-81,082 kg; 73\% of the total loss), indicating that oak species account for a large portion of the damage. The species with the most percent gain in this plot were American elm (139\%, $285 \mathrm{~kg})$ and possumhaw $(103 \%, 106 \mathrm{~kg})$. The species with the most biomass gain were bald cypress ( $3,144 \mathrm{~kg} ; 16 \%$ gain) and tallow $(3,400 \mathrm{~kg}$; was not present as an adult in the plot in 2004). Overall, eleven of the 17 species that were present in 2004 experienced net biomass loss between 2004 and 2011 and six species experienced gain.

\subsubsection{3}

\section{Cypress Tupelo Plot}

The Cypress Tupelo plot was not placed in Table 4 because there is no data from 2004 to 2006. However, there were no dead trees found in the plot in 2006 which indicated that there was no major biomass loss from Hurricane Katrina (loss still occurred from snapped trees and damaged crowns but not whole tree loss). Between 2006 and 2011, this plot had a net percent biomass gain of 4\% $(9,546 \mathrm{~kg})$. All four adult species in the plot experienced a net gain. Red maple gained $4.7 \%$ (1.3kg), water tupelo gained $1 \%(2,384 \mathrm{~kg}$; lost $13,169 \mathrm{~kg}$ to dead trees but gained 15,553 $\mathrm{kg}$ from growth and new adult recruitment), blackgum gained 3\% (216 kg) and bald cypress gained $16 \%(6,894 \mathrm{~kg})$. 


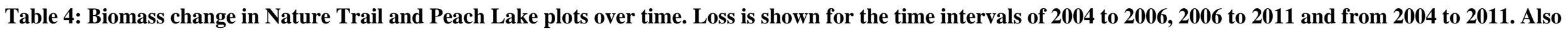
total biomass lost or gained from both plots is shown.

\begin{tabular}{|c|c|c|c|c|c|c|c|c|c|c|c|c|c|c|c|c|c|c|}
\hline \multirow[b]{3}{*}{ Scientific Name } & \multicolumn{6}{|c|}{ Nature Trail Plot } & \multicolumn{6}{|c|}{ Peach Lake Plot } & \multicolumn{6}{|c|}{ Totals } \\
\hline & \multicolumn{2}{|c|}{ 2004-2006 } & \multicolumn{2}{|c|}{ 2006-2011 } & \multicolumn{2}{|c|}{ 2004-2011 } & \multicolumn{2}{|c|}{ 2004-2006 } & \multicolumn{2}{|c|}{ 2006-2011 } & \multicolumn{2}{|c|}{ 2004-2011 } & \multicolumn{2}{|c|}{ 2004-2006 } & \multicolumn{2}{|c|}{ 2006-2011 } & \multicolumn{2}{|c|}{ 2004-2011 } \\
\hline & $\%$ & $\mathrm{~kg}$ & $\%$ & $\mathrm{~kg}$ & $\%$ & $\mathrm{~kg}$ & $\%$ & $\mathrm{~kg}$ & $\%$ & $\mathrm{~kg}$ & $\%$ & $\mathrm{~kg}$ & $\%$ & $\mathrm{~kg}$ & $\%$ & $\mathrm{~kg}$ & $\%$ & $\mathrm{~kg}$ \\
\hline Acer rubrum & $-18 \%$ & $-1,643$ & $-4 \%$ & $-3,172$ & $-53 \%$ & $-4,815$ & $-79 \%$ & $-5,893$ & $-2 \%$ & -35 & $-79 \%$ & $-5,928$ & $-46 \%$ & $-7,535$ & $-36 \%$ & $-3,206$ & $-65 \%$ & $-10,742$ \\
\hline Carpinus caroliniana * & $-65 \%$ & $-4,780$ & $19 \%$ & 484 & $-59 \%$ & $-4,296$ & $-44 \%$ & -900 & $68 \%$ & 795 & $-5 \%$ & -105 & $-61 \%$ & $-5,679$ & $35 \%$ & 1,279 & $-47 \%$ & $-4,400$ \\
\hline Carya aquatica & $-9 \%$ & -24 & $67 \%$ & 151 & $51 \%$ & 127 & $-8 \%$ & -219 & $-25 \%$ & -649 & $-31 \%$ & -868 & $-8 \%$ & -242 & $-18 \%$ & -498 & $-24 \%$ & -740 \\
\hline Diospyros virginiana & $-5 \%$ & -6 & $-40 \%$ & -46 & $-43 \%$ & -52 & $-36 \%$ & -105 & $-100 \%$ & -188 & $-100 \%$ & -293 & $-27 \%$ & -110 & $-77 \%$ & -233 & $-83 \%$ & -344 \\
\hline Fagus grandifolia ${ }^{\dagger}$ & & & & 101 & & 101 & & & & & & & & & & 142 & & 142 \\
\hline Fraxinus pennsylvanica & & & & & & & $-25 \%$ & $-3,436$ & $-6 \%$ & -648 & $-29 \%$ & $-4,085$ & $-25 \%$ & $-3,436$ & $-6 \%$ & -648 & $-29 \%$ & $-4,084$ \\
\hline Ilex decidua * & & & & & & & $-45 \%$ & -46 & $267 \%$ & 152 & $103 \%$ & 106 & $-45 \%$ & -45 & $267 \%$ & 15 & $103 \%$ & 105 \\
\hline Ilex opaca* & $-36 \%$ & $-1,025$ & $4 \%$ & 69 & $-34 \%$ & -956 & $-10 \%$ & -4 & $13 \%$ & 5 & $2 \%$ & 1 & $-36 \%$ & $-1,029$ & $4 \%$ & 74 & $-33 \%$ & -955 \\
\hline Ilex verticillata * & & & & & & & $-28 \%$ & -38 & $-57 \%$ & -57 & $-69 \%$ & -94 & $-28 \%$ & -37 & $-57 \%$ & -56 & $-69 \%$ & -94 \\
\hline Liquidamber styraciflua & $-38 \%$ & $-14,012$ & $-29 \%$ & $-6,451$ & $-56 \%$ & $-20,464$ & $-40 \%$ & $-15,209$ & $-32 \%$ & $-7,253$ & $-59 \%$ & $-22,462$ & $-39 \%$ & $-29,221$ & $-30 \%$ & $-13,704$ & $-58 \%$ & $-42,926$ \\
\hline Magnolia grandiflora & $21 \%$ & 16 & $280 \%$ & 261 & $360 \%$ & 277 & & & & & & & $21 \%$ & 16 & $281 \%$ & 260 & $360 \%$ & 277 \\
\hline Magnolia virginiana & $-27 \%$ & -451 & $5 \%$ & 55 & $-24 \%$ & -396 & & & & & & & $-27 \%$ & -451 & $5 \%$ & 55 & $-24 \%$ & -396 \\
\hline Nyssa aquatica & & & & & & & $-3 \%$ & -203 & $4 \%$ & 328 & $2 \%$ & 125 & $-3 \%$ & -203 & $4 \%$ & 328 & $2 \%$ & 124 \\
\hline Nyssa sylvatica & $-27 \%$ & $-1,842$ & $-6 \%$ & -302 & $-32 \%$ & $-2,143$ & $-3 \%$ & -161 & $-55 \%$ & $-3,062$ & $-56 \%$ & $-3,233$ & $-16 \%$ & $-2,002$ & $-32 \%$ & $-3,363$ & $-43 \%$ & $-5,366$ \\
\hline Ostrya virginiana & $-14 \%$ & -6 & $140 \%$ & 50 & $100 \%$ & 45 & & & & & & & $-14 \%$ & -6 & $139 \%$ & 50 & $106 \%$ & 45 \\
\hline Planera aquatica & & & & & & & $-37 \%$ & -241 & $85 \%$ & 336 & $15 \%$ & 95 & $-38 \%$ & -240 & $85 \%$ & 335 & $15 \%$ & 94 \\
\hline Quercus laurifolia & $0 \%$ & 0 & $233 \%$ & 126 & $231 \%$ & 125 & $-57 \%$ & $-41,412$ & $-57 \%$ & $-17,579$ & $-81 \%$ & $-58,991$ & $-57 \%$ & $-41,412$ & $-56 \%$ & $-17,453$ & $-81 \%$ & $-58,865$ \\
\hline Quercus lyrata & & & & & & & $-78 \%$ & $-16,436$ & $-17 \%$ & -804 & $-81 \%$ & $-17,240$ & $-78 \%$ & $-16,436$ & $-17 \%$ & -804 & $-81 \%$ & $-17,240$ \\
\hline Quercus michauxii & $-8 \%$ & -511 & $6 \%$ & 352 & $-2 \%$ & -159 & & & & & & & $-8 \%$ & -510 & $6 \%$ & 351 & $-2 \%$ & -659 \\
\hline Quercus nigra & $-53 \%$ & $-43,185$ & $-5 \%$ & $-1,850$ & $-55 \%$ & $-45,035$ & $-54 \%$ & $-3,518$ & $-45 \%$ & $-1,332$ & $-75 \%$ & $-4,850$ & $-53 \%$ & $-46,703$ & $-8 \%$ & $-3,181$ & $-57 \%$ & $-49,884$ \\
\hline Taxodium distichum & & & & & & & $4 \%$ & 803 & $11 \%$ & 2,341 & $16 \%$ & 3,144 & $4 \%$ & 503 & $11 \%$ & 2,340 & $16 \%$ & 3,143 \\
\hline Triadica sebiferat & & & & & & & $0 \%$ & & & 3,400 & & 3,400 & & & & 3,400 & & 3,400 \\
\hline \multirow[t]{2}{*}{ Ulmus americana } & $15 \%$ & 38 & $154 \%$ & 463 & $191 \%$ & 501 & $-3 \%$ & -5 & $146 \%$ & 290 & $139 \%$ & 285 & $7 \%$ & 32 & $151 \%$ & 753 & $169 \%$ & 786 \\
\hline & $-44 \%$ & $-67,429$ & $-11 \%$ & $-9,691$ & $-50 \%$ & $-77,121$ & $-44 \%$ & $-87,025$ & $-21 \%$ & $-23,961$ & $-56 \%$ & $-110,986$ & $-44 \%$ & $-154,455$ & $-17 \%$ & $-33,628$ & $-53 \%$ & $-188,083$ \\
\hline
\end{tabular}

*understory species

† not present in the plot in 2004 


\section{4}

\section{Discussion}

This study revealed that delayed mortality to hurricane-damaged trees is a significant factor in the long-term dynamics of bottomland hardwood forests and represents an amplification of the effects of the hurricane over time. One must be cautious estimating hurricane effects based solely on immediate surveys. In 2006 , direct mortality in the surveyed plots was found to be $22 \%$, similar to the $20 \%$ found after Hurricane Katrina in other plots in the same management area (Chapman et al. 2008). When both of the bottomland hardwood forest plots are taken together, annual mortality from 2004 to 2006 was 11\% (direct hurricane mortality) and 5\% from 2006 to 2011 (delayed hurricane mortality), indicating that high annual mortality rates are maintained for many years after hurricane passage. Background mortality in these forests is $1.9 \%$ per year (Chapman et al. 2008). Delayed mortality seems to be a widespread phenomenon among a variety of tree species in different ecosystems following hurricanes. In Sri Lanka, for example, high forest mortality rates continued for 42 months after a cyclone (Lugo and Scatena 1996); in North Carolina mortality rates two times higher than background mortality rates were found five years after Hurricane Fran (Xi et al. 2008); in northern Florida direct mortality was 6.9\% (equaling the background mortality for the seven years prior to the hurricane) and delayed mortality for the next seven years was $8.8 \%$ which was a $30 \%$ increase over the seven years before the hurricane (Batista and Platt 2003); and in Louisiana, mortality rates were similar to pre-Hurricane Andrew immediately after the storm but then increased in subsequent years as damaged trees died (Conner et al. 2002). Surveying delayed mortality is important in order to be able to assess the true effects of hurricanes at a forest and species level. This is especially true when direct and delayed mortality occur at different rates in different species. For example, direct mortality in water oak was significantly greater than sweetgum but six years later sweetgum annual mortality rate was equal to water oak at $8 \%$ per year. 
Direct and delayed morality may cause forest species composition to change over time.

Reduction in number of sweetgum, water oak and laurel oak adults, the corresponding lack of sweetgum in the sapling layer and the low representation of the three species in the seedling layer (Henkel, unpublished data), indicate that the hurricane produced long-term changes in species composition. By comparing pre- and post-hurricane data Zhao et al. (2006) found that in highly damaged areas, the hurricane acted to accelerate succession by killing established pioneer species, which allowed for establishment of more shade-tolerant, climax species. In another study, bottomland hardwood species composition changed after Hurricane Andrew due to the invasion of tallow in ridge communities (Conner et al. 2014). In contrast, other studies did not document a change in species composition due to hurricane passage (Walker 1991; Batista and Platt 2003; Xi et al. 2008; Harcombe et al. 2009; Keeland and Gorham 2009). The ecological consequences of species specific mortality can be far reaching. First, historical seed sources may not be present so regeneration of species that experience high damage may be delayed, especially in species with animal (besides bird) dispersed seeds such as oaks, where a distance of 60 to 80 meters from the seed source can delay natural recruitment indefinitely (Battaglia et al. 2002). The reduction in seed source of different species may also mean a reduction in food source for animals that rely on a specific suite of species. This could have trophic cascade effects on predator/prey relationships.

Measuring delayed mortality is also important for estimating biomass loss in the forest and therefore dedicated carbon releases into the atmosphere. One study found that the carbon loss due solely to the damage and mortality to trees from Hurricane Katrina was $92 \mathrm{Tg}$ to $112 \mathrm{Tg}$, which is equivalent to 50 to $140 \%$ of the estimated net annual U.S. carbon sink (Chambers et al. 2007). The field portion of the Chambers et al. (2007) study was based on damage and mortality surveys done in the PRWMA in 2006 after Hurricane Katrina. With the subsequent mortality estimated here taken into account, the carbon loss due to Hurricane Katrina is significantly higher. This provides insight that there 
is a large flux of carbon (dedicated loss) that would not be accounted for if only direct or immediate mortality is surveyed in these forests. These updated biomass loss estimates are important to incorporate into larger climate change models that must consider these additional losses given that hurricane frequency and intensity are expected to increase and has been doing so for the past 30 years, especially in the North Atlantic Ocean (Emanuel 2005; Webster et al. 2005; Running 2008; Saunders and Lea 2008; Wu and Wang 2008; Uriarte et al. 2009; Negron-Juarez et al. 2010). Dedicated releases of $\mathrm{CO}_{2}$ to the atmosphere from impacted forests for a number of years after a catastrophic event is an important aspect of regional and global carbon cycling, and accurately predicting these losses (both immediate and long-term) will add valuable data to climate change models.

Direct and delayed mortality opens an area for species invasion which was observed in the management area. Chapman et al. (2008) observed immediately after Hurricane Katrina that there "were areas carpeted with tallow seedlings and saplings" and suggested future study on tallow invasion. The present study revealed that five years later, tallow had indeed invaded new areas in the forest with significant recruitment into the adult stage class making the long-term impact of the hurricane more apparent. Surveys from Growth Management Plots (managed by the Louisiana Department of Wildlife and Fisheries) did not find adult tallow in surveys that covered four hectares in 1989; ten years later in 1998 there were two tallow adults ( 14 and $12 \mathrm{~cm} \mathrm{DBH}$ ) in these plots and by 2005 there were three. Thus, in a much larger area surveyed than the Peach Lake plot ( $0.56 \mathrm{ha})$ only three new adults recruited into the plots in 16 years whereas 63 new adults (some of which were producing seeds in 2011) recruited into the Peach Lake plot in five years after the hurricane. Also, from multiple surveys in 2006 that covered 6.7 ha in the PRWMA, only three tallow adults were found. There have been studies that have found elevated tallow recruitment after hurricane or wind disturbance, but in most cases not to the severity seen here. Studies conducted in Louisiana (Keeland and Gorham 2009; Middleton 2009; Howard 2012), South Carolina (Conner et al. 2005) and Texas (Harcombe et al. 2009) found that tallow 
populations expanded (increased density and/or importance value) after hurricane passage, but in all these cases, tallow was present as an adult prior to the hurricane, although two studies did find tallow in plots after a hurricane where it had not previously been found (Conner et al. 2002; Conner et al. 2014).

Tallow invasion in the study forest was prolific for reasons having to do with the characteristics of tallow and some having to do with the characteristics of the environment. Tallow is a good invader because it has high growth rates that far exceed the growth rates of most native species (Scheld and Cowles 1981; Jones and McLeod 1989; Conner et al. 2001; Siemann and Rogers 2003; Butterfield et al. 2004; Siemann and Rogers 2006; Nijjer et al. 2008; Zou et al. 2009). Tallow also produces an extensive seed bank with seeds remaining viable up to seven years (more commonly three to four years), germinates throughout the growing season (Cameron et al. 2000; Conner et al. 2001) and produces copious amounts of seeds. Siemann et al. (2006) found that tallow could produce an average of 273 seeds $/ \mathrm{m}^{2} / \mathrm{yr}$ while water oak produced fewer than $0.6 / \mathrm{m}^{2} /$ year. Tallow seeds are dispersed great distances by water and birds (Bruce et al. 1997; Renne et al. 2001; Conway et al. 2002; Renne et al. 2002) and seed viability is high at $88-98 \%$ (Bruce 1993).

Environmental characteristics also played a role in the successful invasion by tallow. High light habitats were abundant after the hurricane and tallow readily invades high light and disturbed environments and grows more rapidly in the sun than the shade (Jones and McLeod 1989; Matlack 2002; Siemann and Rogers 2003; Pattison and Mack 2009; Zou et al. 2009). Hurricane induced tree mortality also reduces competition and increases available nutrients (Rybczyk et al. 1992; Loope et al. 1994; Carlton and Bazzaz 1998; Snitzer et al. 2005) since leaf nutrients have not been translocated from the leaves and natural leeching has not occurred (Rybczyk et al. 1992). This would particularly benefit tallow because tallow growth rates increase with nutrient addition (Siemann and Rogers 2003; Siemann and Rogers 2007). 
In addition to the environment created by the hurricane there are some characteristics of the PRWMA that also may have facilitated the spread of tallow. During the winters and early springs of 2003 to 2006, the Pearl River overflowed its banks, and in some years the entire management area was flooded. Tallow release seeds from September to December. Therefore, during the winter and spring, newly released seeds could be transported over the entire management area by flood waters and incorporated into the seed bank and would be present when ideal conditions were created by the hurricane. During extensive field work in the forests of the management area, not many large, seed producing tallow were observed, but they were observed growing along roads and trails, which is confirmed by Chapman et al. (2008). Also, tallow invasion was most prolific at lower elevations (1.5 m) which are flooded more frequently, creating environments that tallow readily invades (Gan et al. 2009; Wang et al. 2011). Therefore, the inherent high growth rates and seed production of tallow, with the ideal environmental conditions created by the hurricane and the flooding regime and seasonal dynamics of the PRWMA facilitated the invasion and spread of tallow in the management area. A question for future study would be to investigate the genetic relationship between tallow germinated after Hurricane Katrina and the older, larger seed trees found on the management area roads in order to ascertain if tallow spread is from seed sources within the management area or if outside sources are contributing to the invasion.

Some studies have investigated the potential spread of tallow into new areas (Gan et al. 2009; Pattison and Mack 2009; Wang et al. 2011). While these studies mentioned or actively modeled the effects of temperature increase on the spread of tallow, only one mentions the effects of disturbances (Gan et al. 2009) and did not specifically model increasing hurricane intensity or frequency in relation to tallow spread. This study proves that considering large wind disturbances when predicting tallow expansion inland and northward is important as tallow can readily invade and dominate new areas within five years after a hurricane. Although Hurricane Katrina caused significant mortality in the 
PRWMA, its effects on species composition may not have been long lasting had it not been for the invasion of tallow. In areas where tallow did not invade, it seems that the forest will recover to a similar species composition that was present before. In areas where tallow did invade, there are significant changes to the forest. The new area of invasion will now provide additional seed sources for tallow to continue moving upland and inland to higher elevations, where it can establish, perhaps in the understory but more likely in gaps. With tallow's short time to reproductive maturity (3 to 7 years), new seed sources will become available rapidly and tallow will continue to spread. Management efforts may be best concentrated in not allowing tallow to initially establish by being vigilant along forest edges, roads, or areas with an open canopy and removing any newly established tallow. Once tallow is established, eradication will be difficult and costly, especially in areas where there are many vectors for dispersal in the form of rivers, bayous, canals and areas that are periodically flooded. For this reason, managers should also be vigilant along waterways and remove established tallow, a task that may be impossible in southern Louisiana where extensive water networks exist.

The importance and prevalence of delayed mortality may also have economic and ecological implications. When managers are assessing hurricane losses in timberlands, measuring only immediate and direct mortality may severely underestimate the total losses and therefore timberland companies are not adequately compensated. Hurricane Katrina damaged approximately five million hectares of timberland (of a total of 16 million) with a loss of 22 million cubic meters of timber in Mississippi, Alabama and Louisiana, $90 \%$ of which was within 60 miles of the coast (FIA 2005) and valued at $\$ 1.4$ to $\$ 2.4$ billion (Stanturf et al. 2007). Estimates of delayed mortality (up to five years) are mentioned as a necessity for accurately assessing losses (Stanturf et al. 2007) but are not quantified. The rates of delayed mortality for each species under different rates of damage found in the present study could be used by forest managers to forecast additional losses to timber value. 


\section{5}

In conclusion, the assessment of delayed mortality in the PRWMA revealed that forest impacts from hurricanes last for years after the hurricane as damaged trees continue to die. The fact that direct and delayed mortality is different by species indicates that the measurement of direct mortality only can lead to false conclusions about which species are resistant to hurricanes as trees that appear to survive the hurricane subsequently die, not being able to recover from sustained damage. In general, the oak species (Quercus spp.) experienced high rates of direct hurricane mortality while sweetgum (Liquidamber styraciflua) experienced high rates of delayed mortality. Understory species experienced high mortality, most likely due to collateral damage from falling canopy trees. Species that were resistant to hurricane damage included those species that dominate in swamp habitats in southeastern Louisiana but are present in bottomland hardwood forest, including bald cypress (Taxodium distichum) and water tupelo (Nyssa aquatica).

The direct and delayed mortality opened up new habitat for invasion by tallow which grew prolifically in high damaged bottomland hardwood forest areas that were periodically inundated (conditions found in the Peach Lake plot). Additionally, tallow was able to recruit at a high rate into the adult tree class, indicating that large disturbances are an important factor in accelerating the expansion of tallow populations. Although a broad survey was not conducted outside of the Peach Lake plot, it is expected that similar areas, with high damage and periodic inundation, contain widespread tallow populations. The high mortality of some species, low recruitment of these species into the sapling and adult layers and the corresponding expansion of tallow indicates that species composition will be different than pre-hurricane composition for some time in the future. The post-hurricane tallow population expansion makes this region susceptible to further invasion by providing seed sources that can move inland and upland, especially after future large disturbances.

\section{Acknowledgements}


This study was supported by a grant from the National Institute for Climatic Change Research Coastal Center, which was sponsored by DOE's Office of Biological and Environmental Research. We also would like to thank the Louisiana Department of Wildlife and Fisheries for allowing access and research to occur on their land at the Pearl River Wildlife Management Area. We also thank the two anonymous reviewers for their thoughtful comments on this manuscript. 


\section{References}

Allen, B. P., R. R. Sharitz, and P. C. Goebel. 2005. Twelve years post-hurricane liana dynamics in an oldgrowth southeastern floodplain forest. Forest Ecology and Management 218(1-3):259-269.

Batista, W. B., and W. J. Platt. 2003. Tree population responses to hurricane disturbance: syndromes in a south-eastern USA old-growth forest. Journal of Ecology 91(2):197-212.

Battaglia, L. L., P. R. Minchin, and D. W. Pritchett. 2002. Sixteen years of old-field succession and reestablishment of a bottomland hardwood forest in the Lower Mississippi Alluvial Valley. Wetlands 22(1):1-17.

Battaglia, L. L., R. R. Sharitz, and P. R. Minchin. 1999. Patterns of seedling and overstory composition along a gradient of hurricane disturbance in an old-growth bottomland hardwood community. Canadian Journal of Forest Research-Revue Canadienne De Recherche Forestiere 29(1):144-156.

Brenneman, B., D. Frederick, W. Gardner, L. Schoenhofen, and P. L. Marsh. 1978. Biomass of species and stands of West Virginia hardwoods.in Proceedings of the Central Hardwood Forest Conference II, Purdue, IN pp.159-178.

Bruce, K. A. 1993. Factors affecting the biological invasion of the exotic Chinese tallow tree, Sapium sebiferum, in the Gulf Coast Prairie of Texas. MS Thesis, University of Houston, Houston, Texas.

Bruce, K. A., C. G. N., P. A. Harcombe, and G. Jubinsky. 1997. Introduction, impact on native habitats, and management of a woody invader, the Chinese tallow tree (Sapium sebiferum (L.) Roxb.). Natural Areas Journal 17255-260.

Butterfield, B. J., W. E. Rogers, and E. Siemann. 2004. Growth of Chinese tallow tree (Sapium sebiferum) and four native trees under varying water regimes. Texas Journal of Science 56(4):335-346.

Cameron, G. N., E. G. Glumac, and B. D. Eshelmans. 2000. Germination and dormancy in seeds of Sapium sebiferum (Chinese tallow tree). Journal of Coastal Research 16(2):391-395.

Carlton, G. C., and F. A. Bazzaz. 1998. Resource congruence and forest regeneration following an experimental hurricane blowdown. Ecology 79(4):1305-1319.

Chambers, J. Q., J. I. Fisher, H. C. Zeng, E. L. Chapman, D. B. Baker, and G. C. Hurtt. 2007. Hurricane Katrina's carbon footprint on U. S. Gulf Coast forests. Science 318(5853):1107-1107.

Chapman, E. L., J. Q. Chambers, K. F. Ribbeck, D. B. Baker, M. A. Tobler, H. C. Zeng, and D. A. White. 2008. Hurricane Katrina impacts on forest trees of Louisiana's Pearl River basin. Forest Ecology and Management 256(5):883-889.

Clark, A. I., D. Phillips, and D. Frederick. 1986a. Weight, volume, and physical properties of major hardwood species in Piedmont.in Forest Service Research Paper SE-255 pp.1-66.

Clark, A. I., D. Phillips, and D. Frederick. 1986b. Weight, volume, and physical properties of major hardwood species in upland-south.in Forest Service Research Paper SE-257 pp.1-55.

Colbert, K. C., D. R. Larsen, and J. R. Lootens. 2002. Height-diameter equations for thirteen Midwestern bottomland hardwood species. Northern Journal of Applied Forestry 19(4):171-176.

Conner, W. H., J. A. Duberstein, J. W. Day, and S. Hutchinson. 2014. Impacts of changing hydrology and hurricanes on forest structure and growth along a flooding/elevation gradient in a south Louisiana forested wetland from 1986 to 2009. Wetlands 34(4):803-814.

Conner, W. H., L. W. Inabinette, and C. A. Lucas. 2001. Effects of flooding on early growth and competitive ability of two native wetland tree species and an exotic. Castanea 66(3):237-244.

Conner, W. H., L. Mihalia, and J. Wolfe. 2002. Tree community structure and changes from 1987 to 1999 in three Louisiana and three South Carolina forested wetlands. Wetlands 22(1):58-70.

Conner, W. H., W. D. Mixon, and G. W. Wood. 2005. Maritime forest habitat dynamics on Bulls Island, Cape Romain National Wildlife Refuge, SC, following Hurricane Hugo. Forest Ecology and Management 212(1-3):127-134. 
Conway, W. C., L. M. Smith, and J. F. Bergan. 2002. Avian use of Chinese tallow seeds in coastal Texas. Southwestern Naturalist 47(4):550-556.

Curtis, J. T., and R. P. Mclntosh. 1951. An upland forest continuum in the prairie-forest boarder region of Winsconsin. Ecology 32(3):476-496.

Emanuel, K. 2005. Increasing destructiveness of tropical cyclones over the past 30 years. Nature 436(7051):686-688.

Fatemi, F. R., R. D. Yanai, S. P. Hamburg, M. A. Vadeboncoeur, M. A. Arthur, R. D. Briggs, and C. R. Levine. 2011. Allometric equations for young northern hardwoods: the importance of age-specific equations for estimating aboveground biomass. Canadian Journal of Forest Research 41881-891.

FIA. 2005. Potential timber damage due to Hurricane Katrinain Mississippi, Alabama and Louisiana, September 22, 2005. Forest Inventory and Analysis, Southern Research Station http://www.srs.fs.usda.gov/katrina/katrina_brief_2005-09-22.pdf.

Gagnon, P. R., and W. J. Platt. 2008. Multiple disturbances accelerate clonal growth in a potentially monodominant bamboo. Ecology 89(3):612-618.

Gagnon, P. R., W. J. Platt, and E. B. Moser. 2007. Response of a native bamboo [Arundinaria gigantea (Walt.) Muhl.] in a wind-disturbed forest. Forest Ecology and Management 241(1-3):288-294.

Gan, J. B., J. H. Miller, H. H. Wang, and J. W. Taylor. 2009. Invasion of tallow tree into southern US forests: influencing factors and implications for mitigation. Canadian Journal of Forest ResearchRevue Canadienne De Recherche Forestiere 39(7):1346-1356.

Greig-Smith, P. 1983. Quantitative plant ecology. 3rd edition. Blackwell Scientific Publications, Boston, MA.

Gresham, C. A., T. M. Williams, and D. J. Lipscomb. 1991. Hurricane Hugo wind damage to southeastern United States coastal forest tree species. Biotropica 23(4):420-426.

Harcombe, P. A., L. E. M. Leipzig, and I. S. Elsik. 2009. Effects of Hurricane Rita on three long-term forest study plots in east TExas, USA Wetlands 29(1):88-100.

Howard, J. J. 2012. Hurricane Katrina Impact on a Leveed Bottomland Hardwood Forest in Louisiana. American Midland Naturalist 168(1):56-69.

Jenkins, J. C., D. C. Chojnacky, L. S. Heath, and R. A. Birdsey. 2003. National-scale biomass estimators for United States tree species. Forest Science 49(1):12-35.

Jones, R. H., and K. W. McLeod. 1989. Shade tolerance in seedlings of Chinese tallow tree, American sycamore, and cherrybark oak. Bulletin of the Torrey Botanical Club 116(4):371-377.

Keeland, B. D., and L. E. Gorham. 2009. Delayed tree mortality in the Atchafalaya basin of Southern Louisiana following Hurricane Andrew. Wetlands 29(1):101-111.

Kent, M. 2012. Vegetation description and data analysis. 2nd edition. Wiley-Blackwell, Hoboken, NJ.

Loope, L., M. Duever, A. Herndon, J. Snyder, and D. Jansen. 1994. Hurricane impact on uplands and fresh-water swamp forest. Bioscience 44(4):238-246.

Lugo, A. E., and F. N. Scatena. 1996. Background and catastrophic tree mortality in tropical moist, wet, and rain forests. Biotropica 28(4):585-599.

Martin, J. G., B. D. Kloeppel, T. L. Schaefer, D. L. Kimbler, and S. G. McNulty. 1998. Aboveground biomass and nitrogen allocation of ten deciduous southern Appalachian tree species. Canadian Journal of Forest Research-Revue Canadienne De Recherche Forestiere 28(11):1648-1659.

Matlack, G. R. 2002. Exotic plant species in Mississippi, USA: Critical issues in management and research. Natural Areas Journal 22(3):241-247.

Middleton, B. A. 2009. Effects of Hurricane Katrina on tree regeneration in Taxodium distichum swamps of the gulf coast. Wetlands 29(1):135-141.

Negron-Juarez, R., D. B. Baker, H. C. Zeng, T. K. Henkel, and J. Q. Chambers. 2010. Assessing hurricaneinduced tree mortality in U.S. Gulf Coast forest ecosystems. Journal of Geophysical ResearchBiogeosciences 115. 
Nijjer, S., W. E. Rogers, C. T. A. Lee, and E. Siemann. 2008. The effects of soil biota and fertilization on the success of Sapium sebiferum. Applied Soil Ecology 38(1):1-11.

Pattison, R. R., and R. N. Mack. 2009. Environmental constraints on the invasion of Triadica sebifera in the eastern United States: an experimental field assessment. Oecologia 158(4):591-602.

Renne, I. J., W. C. Barrow, L. A. J. Randall, and W. C. Bridges. 2002. Generalized avian dispersal syndrome contributes to Chinese tallow tree (Sapium sebiferum, Euphorbiaceae) invasiveness. Diversity and Distributions 8(5):285-295.

Renne, I. J., T. P. Spira, and W. C. Bridges. 2001. Effects of habitat, burial, age and passage through birds on germination and establishment of Chinese tallow tree in coastal South Carolina. Journal of the Torrey Botanical Society 128(2):109-119.

Running, S. W. 2008. Climate change - Ecosystem disturbance, carbon, and climate. Science 321(5889):652-653.

Rybczyk, J. M., X. W. Zhang, J. W. Day Jr., I. Hesse, and S. Feagley. 1992. The impact of Hurricane Andrew on tree mortality, litterfall, nutrient flux, and water quality in a Louisiana coastal swamp forest. Journal of Coastal Research(SI NO. 21):340-353.

Saunders, M. A., and A. S. Lea. 2008. Large contribution of sea surface warming to recent increase in Atlantic hurricane activity. Nature 451(7178):557-U553.

Scheld, H. W., and J. R. Cowles. 1981. Woody biomass potential of the Chinese tallow tree. Economic Botany 35(4):391-397.

Schlaegel, B. E. 1984. Green ash volume and weight tables.in U.S. Forest Service Research Paper SO - 206 pp.1-14.

Sheil, D., D. Burslem, and D. Alder. 1995. The interpretation and misinterpretation of mortality rate measures. Journal of Ecology 83331-333.

Siemann, E., and W. E. Rogers. 2003. Changes in light and nitrogen availability under pioneer trees may indirectly facilitate tree invasions of grasslands. Journal of Ecology 91(6):923-931.

Siemann, E., and W. E. Rogers. 2006. Recruitment limitation, seedling performance and persistence of exotic tree monocultures. Biological Invasions 8(5):979-991.

Siemann, E., and W. E. Rogers. 2007. The role of soil resources in an exotic tree invasion in Texas coastal prairie. Journal of Ecology 95689-697.

Siemann, E., W. E. Rogers, and S. J. Dewalt. 2006. Rapid adaptation of insect herbivores to an invasive plant. Proceedings of the Royal Society B-Biological Sciences 273(1602):2763-2769.

Snitzer, J. L., D. H. Boucherand, and K. L. Kyle. 2005. Response of exotic invasive plant species to forest damage caused by Hurricane Isabel., Chesapeake Bay Research Consortium CRC publication 05160, Edgewater, MD.

Stanturf, J. A., S. L. Goodrick, and K. W. Outcalt. 2007. Disturbance and coastal forests: A strategic approach to forest management in hurricane impact zones. Forest Ecology and Management 250(1-2):119-135.

Ter-Mikaelian, M. T., and M. D. Korzukhin. 1997. Biomass equations for sixty-five North American tree species. Forest Ecology and Management 97(1):1-24.

Uriarte, M., C. D. Canham, J. Thompson, J. K. Zimmerman, L. Murphy, A. M. Sabat, N. Fetcher, and B. L. Haines. 2009. Natural disturbance and human land use as determinants of tropical forest dynamics: results from a forest simulator. Ecological Monographs 79(3):423-443.

Walker, L. R. 1991. Tree damage and recovery from Hurricane Hugo in Luquillo Experimental Forest, Puerto Rico Biotropica 23(4):379-385.

Wang, H. H., W. E. Grant, T. M. Swannack, J. B. Gan, W. E. Rogers, T. E. Koralewski, J. H. Miller, and J. W. Taylor. 2011. Predicted range expansion of Chinese tallow tree (Triadica sebifera) in forestlands of the southern United States. Diversity and Distributions 17(3):552-565. 
Webster, P. J., G. J. Holland, J. A. Curry, and H. R. Chang. 2005. Changes in tropical cyclone number, duration, and intensity in a warming environment. Science 309(5742):1844-1846.

White, D. A. 1983. Plant communities of the lower Pearl River Basin, Louisiana. American Midland Naturalist 110(2):381-396.

Wu, L. G., and B. Wang. 2008. What has changed the proportion of intense hurricanes in the last 30 years? Journal of Climate 21(6):1432-1439.

Xi, W. M., R. K. Peet, and D. L. Urban. 2008. Changes in forest structure, species diversity and spatial pattern following hurricane disturbance in a Piedmont North Carolina forest, USA. Journal of Plant Ecology-Uk 1(1):43-57.

Zhao, D. H., B. Allen, and R. R. Sharitz. 2006. Twelve year response of old-growth southeastern bottomland hardwood forests to disturbance from Hurricane Hugo. Canadian Journal of Forest Research-Revue Canadienne De Recherche Forestiere 36(12):3136-3147.

Zou, J. W., W. E. Rogers, and E. Siemann. 2009. Plasticity of Sapium sebiferum seedling growth to light and water resources: Inter- and intraspecific comparisons. Basic and Applied Ecology 10(1):7988. 